\title{
Otaku Subculture Character in Japanese Poetry Anthology Otaku Senryu
}

\author{
Indah Fitriani, Lina Meilinawati, N. Rinaju Purnomowulan \\ Universitas Padjadjaran \\ Email: utsukushii_ndah@yahoo.com
}

\begin{abstract}
This paper focuses on one the subcultures existing in Japan, known as otaku. Subculture is a forum for youth community media and technology enthusiasts, like manga (Japanese comics), anime (Japanese cartoons), video games, computers, and the Internet. In the process, otaku who initially labeled negatively has contributed significantly to Japan as the most advanced industrialized country in Asia, not only in the field of culture, but also in the fields of science and economics. Using data from Japanese poem anthology (senryu) in Otaku Senryu(OS), this paper focuses on 1) distinctiveness of otaku character and; 2) factors supporting construction of otaku's character. The method applies Riffaterre's semiotic approach. The result obtained is that the otaku distinctiveness lies in their tendency to not be able to escape media and technology. Media and technology have transformed them into a difficult person in interacting and communicating directly with others as they have become introverted, obsessive, and also consumptive.
\end{abstract}

Keywords: character, otaku, semiotics, senryu, subculture.

\section{INTRODUCTION}

Senryu, the object of this study, is a Japanese original comical poem born in the mid-Edo period (around the 19th century). 'senryu' was named after a Japanese poet named Karai Senryu. In 1757, Karai Senryu began his career as a maekuzuke master. The poem later became the origin of the emergence of senryu.

Maekuzuke was a popular lyrical game played by many people. At first this lyrical game was used as a teaching method to connect lines of poem, but later developed into a popular poetry contest. Maekuzuke's format consists of two parts, namely maeku and tsukeku. The initial part is called maeku with total 14 syllables in sections of 7-7 and tsukeku in total of 17 syllables with 5-7-5 syllable patterns. At the poetry contest, referee (tenja) would announce the maeku part first before participants continue the verse by reciting parts of his tsukeku. Below are some examples:
Maeku part:

moshiyamoshiya to moshiyamoshiya to

just in case it should happen just in case it should happen

and tsukeku part: mizuchaya e kitewawa ofuki hi o kurashi at the teahouse he puffs rings of smoke all day long

(Ueda, 1999:1-2)

After completed with tsukeku part, the overall of the above maekuzuke illustrates a shy boy who secretly likes a waiter who worked in the tea room. The young man incessantly smoked like a chimney and he probably will not stop until the waiter saw his perseverance and took an interest in him. The poem above can still be interpreted even without part of its maeku. Due to the efforts of Karai Senryu, the tsukeku part later was gradually 
recognized as a new genre of poetry with standalone seventeen syllables, without its maeku part. Tsukeku stand-alone section is called senryu.

As poetry genre, senryu possesses several distinctive features and characteristics distinguishing it from other Japanese poetry. First, senryu visible character is seen from its mode of expression, using a colloquial expression called "kōgo" (Yamamoto, 2010: 13). Second, senryu has a "senryu no me" (the eye of senryu). Senryu no me is the way used to view various ideas, lifestyles, and complexity of diverse human relationships directly (Yamamoto, 2010: 13). Diversity issues that occur in the era later are incorporate into a 17 syllables poem with an honest, innocent and playful delivery. In connection with the delivery method, the third characteristic of senryu is "jushinnawarai" (innocent laugh) and "jaki no naiwarai " (laugh without naiveté).

Senryu is also known as comical poem, a genre of poetry popular for its humorous qualities and ability to draw laugh from the reader (Ueda, 1999: viii). At first, the people of Edo (now Tokyo) in the 18th century did not consider senryu as poetry, but only as mere entertainment. Senryu was rated as popular literature, mass produced and consumed in bulk. As a kind of poetry that has entertained millions of readers, W.H. Auden (in Ueda, 1999: 19) defined senryu as "light verse", stating that should be "light" or funny because otherwise people will show disinterest. Laughter element in senryu generally is the same as what was used in the Western world, ranging from customs of contemporary society built around a feeling of superiority. Based on the opinion of the philosophers, such as Plato, Aristotle, and Hobbes, our laugh comes from mixture of superiority and victory, the kind of feeling we have when we encounter incompetence, clumsiness, misfortune or misjudgment on other. (Ueda, 1999: 20).

In relation with the laughter element mentioned above, Otaku Senryu (OS), a senryu anthology as the object of this paper, was also constructed by feelings of superiority of one subculture in Japan, of the otaku. The term otaku originally refers to group of people who loves culture, products, and popular media, such as manga (Japanese comics), anime (Japanese cartoons), online games, Internet, and other related genres. However, the term then became negative label of otaku as form of abnormality. An art editor named Kyoisi Tsuzuki (in Grassmuck, 1990: 9) stated that, "Negative label toward otaku originally refers to them who is ugly, lover-less, dislikes physical touch, is content in collecting silly objects, loves the media, and was cast off socially".

According to Sutrisno (TT: 160), the emergence of subculture was originally a form of rejection and youthful revolt against hegemony of dominant culture, as result of traditional societies shifting into modernity. One form of the resistance was the reinterpretation of culture and creation of a new and different culture, of behavior, lifestyle, style of dress, or music genre. Similar to the emergence of otaku subculture in Japan, its emergence was caused by cultural change in Japanese society in the 1970s. During the era technology advancement promised people that they could master their world simply by pressing a button (via electronic media). Otaku was the frontline of the new exploration. By applying knowledge and information reproduction learned in school, otakus were not content to only consume but they changed, manipulated, and distorted the ideas about various activities and programs, such as manga, anime, game software, and computer (Mac Williams 2008: viii).

The spreading discussion of otaku subculture in Japan attracted Japanese artists to incorporate otaku theme into their work, including into the genre of Japanese poetry called senryu. Through Otaku Senryu, a senryu anthology, this paper attempts to understand the lives of otaku within the cultural change driven by capitalist relations, cyberspace, and postmodernism. Otaku Senryu presents interesting point that on one side people consider otaku lifestyle as a form of deviance, but on the other hand people realize that they do need the otaku. Otaku's ability to change, manipulate and distort ideas about various things is regarded as appealing source in the software field.

Senryu, a poetry genre, is complicated in meaning. Senryu can only be understood with good understanding of the topics featured, the otaku, and with the corresponding theory to dissect senryu. Therefore, in reading the senryus in Otaku Senryu Riffaterre's semiotic approach is applied. With his four concepts, of (1) expression indirectness; (2) 
heuristics and hermeneutics readings; (3) matrices, models and variants; and (4) hypogram, the overall senryu meaning can be analyzed.

Previous research, implementing concept of Riffaterre semiotics into study of poetry, was conducted by Faruk (1996) in an article "Aku dalam Semiotika Riffaterre, Semiotika Riffaterre dalamAku (I'm in Riffaterre Semiotics, Semiotics Riffaterre in me)". In the article, Faruk implemented Riffaterre semiotics in reviewing the poem "Aku" by Chairil Anwar. Based on Riffaterre's 1978 book Semiotics of Poetry, Faruk (1996) stated that since poetry speaks imply something (indirectly), the language used in it differ from everyday language as a result of displacing meaning, creating meaning, and distorting meaning of everyday language. In connection with implementation of Riffaterre's concept into laden with hidden meanings poetry, this paper forwards the question of whether "the concept of semiotics Riffaterre was also applied well into unique language of senryu with its everyday words and slang?" This paper will discuss this question as a part of its center of interests. In addition to the otaku subculture issue covered in the Otaku Senryu, this paper also focuses on two questions: (1) How otaku characters peculiarities were presented in the senryu anthology Senryu Otaku and (2) What factors influenced the construction of the characters otaku?

Furthermore, in interpreting the meaning of poetry, Riffaterre said that the process began with heuristic reading, by normative grammar in accordance with morphological, syntactic, and semantic language. Senryu Otaku is in Japanese therefore reading it is adjusted to normative Japanese grammar. Next, since heuristics reading cannot provide literary meaning, poetry must be reread (retroactively) to provide interpretation (of hermeneutics) (Riffaterre, 1987: 5-6). Hermeneutic readings are based on the reading of literary convention (Pradopo, 2011: 135). In meaning, literary convention serves to discover possibilities of symbolic meanings that entwine meaning of linguistic units. (Faruk, 2012: 148).

The next Riffaterre concept of meaning involves searching for matrices, models and variants in the poems. According to Riffaterre (1978: 19-21), matrix is the keyword leading to the theme which was not made explicit in the text. What is present in the text is the actualization, and the first actualization of the matrix is a model in the form of certain words or phrases. The matrix and model are then transformed into variants of issue in the text. Theme of the poem then could be summarized from the matrices, models, and variants.

In addition to the three concepts of meaning above, Riffaterre (1978) also stated that the meaning of new literary works that comes in relation to other literary works becomes the hypogram. Hypogram is the background of literary works creation. Pradopo (1999) in his article said that other than another literary text, background of this creation could also be social events in the history, the nature and life. Based on the setting described, the paper aims to contribute insights on implementation of Riffaterre semantic concept in one genre of Japanese poetry called senryu. This paper also introduces otaku subculture in Japan.

\section{OTAKU CHARACTER UNIQUENESS}

Referring to previous Tsuzuki's explanation of otaku identity, characteristics of otaku are portrayed by the way they communicate and interact with others, their attitudes and behavior patterns, and their taste. Below is a senryu depicting otaku peculiarities when he communicates with others.

$\begin{array}{ll}\text { キーボード } & \text { kiibōdo } \\ \text { なしで会話は } & \text { nashidekaiwawa } \\ & \text { nodoitai }\end{array}$

喉痛い

Keyboard

Less conversation

throat sore

(OS: 10)

In this senryu, the word keyboard in the line is interpreted as a figure of speech replacing the other implied meaning or what Riffaterre referred as displacing of meaning. Out of types of figurative language, the word keyboard is included in the figure of speech synecdoche pars pro toto (stating the part for the whole). Keyboard here is a board of electronic equipment for computers or mobile phones. In this senryu the use of the word keyboard is selected to represent electronic equipment used 
frequently by otaku in communication, such as computers and mobile phones. In the realm of indirect communication, keyboard serves to replace the function of spoken words into written ones.

The Japanese, in particular otaku, is known as community keyboard. The naming is related the report of Japanese media describing young people of Japan as "generation detached or withdrawn from print (printed letters)" (Ingulsrud, 2009: 2). This is evident from the increasing number of young Japanese who prefer to read or write a novel on their website. This shift of mentality, according to MacWilliams (2008), is caused by the changes in Japan's technology that has given the idea that someone could solve their problems using machines and gadgets. In addition, Grassmuck also said that the otaku has basically become flesh grafts (cyborg) that their life cannot be separated from machine and media. Therefore, the presence of the keyboard is essential for otaku who does not possess the ability to communicate verbally.

For the society, overall literal meaning of the above senryu-that the "conversation without keyboard makes sore throat"-may seem as a hyperbole. For people who are able to communicate verbally, the presence or absence of a keyboard does not cause problem. However, otaku is different. Without the support of communication equipment, such as a keyboard, otaku who has become a human cyborg and possessed no ability in verbal communication will certainly have difficulties in communicating. For otaku who rarely uses his mouth to speak, trying to talk can make his throat ache. Therefore, conversation without a keyboard is causing a throat pain since for otaku keyboard is a substitute of their mouths.

To further explain otaku characters above, the following is senryu depicting otaku's dependence on media as a tool to interact and express opinions.

$\begin{array}{ll}\text { 「寂しくない」 } & \text { "Sabishikunai" } \\ \text { 「人じやない」と } & \text { "Hitorijanai” to } \\ & \text { Kakikomute }\end{array}$

\section{書き込む手}

"Not lonely"

"Not alone"

a writing hand

(OS:41)
The quotation marks in the first and second line of the senryu show directly quoted statements. If the meaning of the language in this senryu is interpreted, the tone gives the impression representing a protest filed by a person who is shown in the third stanza, of hand written. Based on the first and second line statements, of "not lonely" and "not alone", it can be interpreted that the protest comes from an otaku who is always judged as someone who is alone and lonely. In this senryu, the narrator is an otaku. Through this senryu, otaku is stating that they do not feel alone and lonely.

As for the reason why the otaku does not feel lonely, Darmawan (2011: 12) said that otakus basically identified themselves not according to personal relationship with another person but rather to their relationship with realm of objects. This is evident from the otaku habit to spend their free time with media and entertainment products, such as manga, anime, games, Internet, and plastic toys. For otaku, all entertainment media has been providing entertainment and friendship to them. Therefore, although the public has always viewed otaku as being by alone, they do not feel alone and lonely.

Still in connection with the meaning of this senryu, the third verse features a phrase "hand written" showing peculiarities of otaku character who is used in utilizing media to communicate. In this senryu, they say that they are not alone and lonely even if their mouths do not utter words, even if it is their hands that write.

Next, explanation of senryu below will further confirm that otaku is an introvert type of person who cannot express his feelings directly to others.

$\begin{array}{ll}\text { 「ケンカなら } & \begin{array}{l}\text { Kenkanara } \\ \text { omotewadenai } \\ \text { オモテは出ない }\end{array} \\ \text { ネettoni koi }\end{array}$

In the first line, if read heuristically, the word "Kenka" meaning 'fight' is paired with the word "persons", indicating a supposition in the form of a fight that is not necessarily the case. However, 
if the "fight" does happen, what will happen next is described in the second line with the phrase "waomotedenai". The word "omote" in English translates into: the front side (front), face (front), and outside, and the word "denai" is translated as 'does not appear (seem)' and 'not out'. These two words is interpreted simultaneously as a 'do not appear in the front'. Then, the third line contains the phrase "net ni koi" which is the reaction for an argument. The word "net" is derived from the word "Internet", while the word "koi" comes from the word "kimashou" which means an invitation to come forward. The senryu says that for a fight you need to go on the Internet.

If seen from the meaning of the words above and its association with the otaku subculture as the cultural background of its creation, this senryu can be interpreted as an otaku forms of expression. The interpretation becomes matrix in this senryu. This matrix is then made explicit through the model in the form of the phrase "waomotedenai" (do not appear in the front) and "net ni koi" (go on the internet). Based on these two lines, the problem in these senryu variants is the otaku way of expressing feelings when arguing. Otaku's anger expression that does not appear in the front can be interpreted as an introverted attitude tendency of otaku. This is confirmed as otaku expresses their anger over the Internet.

Second, interpretation is continued by linking the meaning of the first and second line with a phrase that is in the third line, "net ni koi" (go on the Internet). From the literal meaning, the variants of existing problems in the third line relate to "how to fight". Earlier it was discussed that during a fight it will not be visible from the outside. How the fight could be invisible from the outside is described in a phrase in the third line, "go on the Internet". The internet presence also indirectly explains the type of otaku as a person who needs the internet as intermediaries to interact with others.

Of the overall meaning, the hypogram of this senryu is that otaku's life cannot be separated from of media and technology dependence. According Grassmuck (1990: 14), otaku is a human cyborg who lives in the age of cyber-media emphasizing mainly on cyberspace. Therefore, high-tech media is the main condition for otaku's survival.
Otaku's obsession with their favorite objects, especially electronic goods, will be described in senryu below.

$\begin{array}{ll}\text { 「死ぬ前に } & \text { Shinumaeni } \\ \text { パソコンだけは } & \text { pasokondakewa } \\ \text { 燃やしたい } & \text { moyashitai }\end{array}$

Before death even with laptop wanting to burn (OS:49)

To be able to capture the whole meaning of this senryu, its interpretation needs to be associated with one particular religious death rituals. This relates to the third line of this senryu that indicates a desire to burn the laptop before dying. Speaking of Japanese tradition, Japan is a country with traditions influenced by teachings of Buddhism and Shinto. In addition, because many influences came from China, the Japanese traditions are influenced by teachings of Confucius. One death ritual related to teachings of Confucius involves offering goods to the symbolic soul of the deceased. The offerings are made by burning items belonging to the deceased, ensuring that these items can be used in the afterlife.

Regarding the word 'laptop' in the second line, the previous section has explained that otaku life relies heavily on media technologies, of mobile phones, computers, or laptop. Based on this, the overall senryu literal meaning indicates that his reliance on technology has made otaku eager to burn his laptop before he died with the hope that he can continue using his laptop in the hereafter. Viewing otaku desire to burn his laptop before he died, it indicates that otaku character possess a lust for material. This is evident from otaku unwillingness to part with his laptop after death.

Otaku obsession of objects shows that otaku has a consumptive nature. Moreover, the pattern of otaku consumerism appears in senryu below.

$\begin{array}{ll}\text { 前買った } & \text { Mae katta } \\ & \text { makimoyomazunitsugi } \\ \text { 巻きも読まずに } & \text { o kau }\end{array}$

次を買う

What was bought has not been read buy another

(OS:174) 
This senryu is derived from a single sentence. Since line by line interpretation is difficult in order to interpret the senryu we must read them as one complete sentence, "Mae kattamakimoyomazunitsugi o kau," which means "Without reading the book you have previously bought, you buy the next book".

By its literal meaning the meaning contained in this senryu is already clear, showing the tendency of consumptive character of otaku. In addition, the otaku action to buy new books even if there are still unread books also shows an otaku trend to act by their desire instead of practicality. With regard to this trend, Azuma (2009: xvi) said that otaku experience animalization, a consumer behavior that diminishes the meaning into human desires. Thus, it can be said that otaku desire to have whatever they like has made them disregard objects' significance. Therefore even if their purchased objects do not provide any benefits, they remain satisfied because their desires are fulfilled.

$\begin{array}{ll}\text { 生活費 } & \text { Seikatsuhi } \\ \text { なくてもこれは } & \text { nakutemo kore wa } \\ \text { 売りません } & \text { urimasen }\end{array}$

Living cost

even without, this

will not be sold

(OS:141)

With heuristic reading, the word "seikatsu" in the first line means 'the costs of everyday life'. Then, the second line includes the word "nakutemo" means "although no'. This word is used to describe the word "seikatsuhi", which combined and translated into "though there was no cost of living'. In addition to the word "nakutemo" in the second line also contains the phrase "kore $w a$ ". In Japanese, the word "kore" is used as pronoun for object nearby, 'this', while " $w a$ " is a particle that follows subject, which in this phrase is "kore". Something that was referred by the word "kore" is not explicitly mentioned in this senryu. However, as already mentioned above, it can be interpreted that "kore" refers to an object. While in the third line the word "urimasen" means "will not be sold".
With hermeneutic reading, the meaning of the stanza, "although there was no cost of living, it will not be sold"' shows an otaku's form of resistance. This resistance shows that when most people would sell anything they have for survival, otaku does the opposite. This senryu illustrates that otaku will keep his possession, indicated by the word "kore", even though there is no more cost to live. If it is associated with otaku's joy, the word "kore" can be interpreted as objects favored by otaku, such as computers, manga, idol shaped plastic dolls, video games, and so on.

Based on the meaning of above senryu, it can be interpreted that otaku is not included in the group of the bourgeoisie since they live a mediocre living. As said by Grassmuck (1990: 10) of their opinion, otaku comes from the working class. However, what makes otaku different with other working class groups is seen in the way they spend money not base on their everyday life needs but out of their enjoyment.

In connection with the typical senryu of using everyday language, the sixth example of senryu above has plainly explained the lifestyle and behavior patterns of otaku being unique and different to other Japanese people in general. Based on the sixth senryu example, it appears that otaku is a generation of young people who depends on machines and technology. This dependence is seen from how they require a medium to communicate and interact. Dependence also makes them consumptive. They never stop consuming what they want without caring to their needs. The construction of otaku characters is of course not only influenced by inner factors, but also influenced by outside factors. The factors that support the construction of otaku's characters are explained further in the following section.

\section{SIGNIFICANT FACTORS IN OTAKU'SCHARACTER CONSTRUCTION}

It is known that otaku owns unique characters of communicating, interacting, having perspectives, and forming their preferences. Details that support the construction of otaku's characters are illustrated by the following senryu. 


\author{
俺のこと \\ 親より知ってる \\ 我がパソコン \\ ore no koto \\ oyayorishitteru \\ wagapasokon
}

About me

More than parents,

understand

my laptop

(OS:142)

The word "ore" in the first line has the same meaning as the word "boku" as the first person pronoun used by men in formal situations. What distinguishes between the use of "ore" and "boku" is situation; "ore" is harsher than the polite "boku". Before "ore" is particle "no" that in Japanese serves as a connector between noun and another noun. In the first line, the word "no" connects "ore" and "koto" means 'thing'. These two words form the meaning of 'my thing/about me'. "Ore" in question does not appear in this senryu. However, when it is associated with senryu's cultural background, "ore" is likely to replace the word "otaku".

The second line includes the word "oya" meaning "parent'. Before "oya" is the word "yori" that translated to be 'rather than the parents'. The word "yori" in this senryu is used to compare the word "oya" to the word "pasokon" which means 'laptop' in the third line. Then, before "pasokon" the phrase "waga" appears to indicate that the laptop belonged to "ore".

If all the lines from above senryu are combined into a proper sentence according to Japanese grammar, the sentence will be "Wagapasokonoyayoriwa ore no koto o shite iru" which means "my laptop understands more about me than my parents". In literal meaning, the senryu matrix is talking about the disappointment felt by otaku. This matrix is made explicit through model in the form of the phrase "ore no koto", "oya" and "pasokon". Problem variant of this model is the disappointment felt by "ore" (otaku) because unlike his laptop, his parents could not understand him very well.

According to Grassmuck (1990: 11), otaku in general is a boy, an only child in the family, whose father is always working and mother is constantly demanding him to study hard so that one day he can go to a university and then work for good company, just as the typical Japanese success story. However, lack of good parenting has made him grow in identity confusion. Moreover, Japanese children tend to spend their free time with media entertainment and technology. As a result, parents and children's communication is hindered. Children are burdened with harsh demands of society from the elderly, and in the end they prefer to hiding behind piles of toys, comics, and their electronic games. This habit is what ultimately causes otaku not able to free himself from media and technology dependence.

The following explains senryu that demonstrate the role of technology and the mass media in shaping otaku's characteristics who is a shut-in from the outside world.

$\begin{array}{ll}\text { カーテンを } & \text { Käten o } \\ \text { 開けずネットで } & \text { akezunetto de } \\ \text { 予報見る } & \text { yohōmiru }\end{array}$

\section{Curtain}

Without opening, on the internet

Searching information

(OS: 33)

The word "kāten"means 'curtain'. But in this senryu, "curtain" is not only interpreted as a cover, but also as something more that shows the boundary between the worlds outside the curtain and the world behind the curtain. In this case, the curtain is regarded as a shield from all the information from outside world. By opening it, people can know and see the state behind the curtain. The circumstances outside the curtain are interpreted as the outside world or the social world.

Furthermore, second and third lines explain that he is able to obtain information on the internet without the need to open the curtain. This has become a hallmark of otaku's characteristics; the shut-in character and is too dependent on the electronic media. In Japan internet sophistication and speed make communication increasingly easy and practical. Without needing to exit a room, people can already find a variety of information via the internet.

Overall, this senryu can show that by using their sophisticated communication media, rather than obtaining information directly otaku relies 
more on electronic media to seek information. In addition, his unwillingness to open the curtain also shows how otakus want to distant themselves from the outside community.

The following is a senryu describing a background of otaku who shut himself from the social world.

$\begin{array}{ll}\text { 知識足す } & \text { Chisikitasu } \\ \text { 足せば足すほど } & \text { tasebatasuhodo } \\ \text { みんなは引く } & \text { minnawahiku }\end{array}$

Add knowledge more and more people retreating (OS:95)

Of the meaning, the poet tries to express irony in this senryu. In general, the more knowledge one has, the more one will look prominent and confident in front of a larger audience. Knowledge can make a person become an influential person not only in the realm of education, but also within society. However, this senryu shows the opposite. The overall meaning of the language of this senryu shows that the more knowledge he has, the more he withdraws from society. This is one of the peculiarities of otaku character that is conveyed by this senryu poet.

Otaku is said to have not cover themselves with trendy clothes, but they cover themselves with information. According Grassmuck (1990: 24), detailed information is an essential element for otaku to communicate with each other. Seeing this characteristic, Okada, an otaku-logy expert, said that true otakus are people who are knowledgeable and intelligent but are awkward in terms of socializing (Ingulsrud, 2009: 53).

By connecting the details above with the senryu of "Kaaten o akezuneeto de Yoho miru" it indicates that otakus are people who like to search for information, especially things that they love. However, they could obtain the information they want through the internet and, therefore, there is no need to go outside. The pleasure in finding information they need in the end absorbs them in their own world, causing them to increasingly withdraw from the outside world.

\section{CONCLUSION}

From the analysis of senryu above, it can be concluded that application of Riffaterre semiotics theory on Japanese poetry senryu, which tends to use everyday language, cannot be well applied. The choice of words with meanings has been explicitly conveyed making it easy to understand the cause. In addition, the short form of the poetry which only consists of 17 syllables also affects its interpreting process. However, without sufficient understanding of senryu creation cultural background, the overall meaning interpretation will become difficult. In addition, readers cannot enjoy senryu as comical poetry that should have drawn laughter from the readers.

Based on the cultural background of the otaku subculture creation, several senryus analyzed above indicate that otaku uniqueness is constructed by their dependence on media technology to communicate and interact with others. This dependence also causes them difficulty to express their opinions or feelings without the help of media. In addition, their obsession on objects they like also affects their lifestyle. They become consumptive and give little care for themselves. Furthermore, the senryu analysis above shows that factors that led to the construction of otaku character in a person are partly due to the lack of attention from their family and the rapid growth of information technology needed by otaku.

\section{REFERENCES}

Alwi, Hasan dkk. (2003). KamusBesar Bahasa Indonesia. Jakarta: BalaiPustaka.

Faruk. (1996). "Aku” dalam Semiotikan Riffaterre Semiotika Riffaterre dalam "Aku"in Jurnal Humaniora Vol 3, hlm 24-33.

(2012). MetodePenelitian Sastra: Sebuah Penjelajahan Awal. Yogyakarta: Pustaka Pelajar.

Gelder, Ken. (2007). Cultural Histories and Social Practice. New York: Routledge.

Grassmuck, Volker. (2004). I'm Alone, but not Lonely. Retrived from (http://www.lazaruscorporation. co.uk/articles/otaku)

Ingulsrud, John. E., dan Kate Allen. (2009). Reading Japan Cool: Patterns of Manga Literacy and Discourse. Amerika: Lexinton Books. 
Liliweri, Alo. (2007). Makna Budaya dalam Komunikasi Antarbudaya. Yogyakarta: LKIS

Macwilliams, Mark Wheeler. (2008). Japanese Visual Culture. New York: M. E. Sharpe.

NN. (2011). Otaku Senryu: Hito wa Mina Nanikashira no Otaku desu. Tokyo: Interlink.

Pradopo, Rachmat Djoko. (1999). "Semiotika: Teori, Metode, dan Penerapannya dalam Pemaknaan Sastra "in Jurnal Humaniora Vol 10, hlm 76-84.

(2011). Beberapa Teori Sastra, Metode Kritik, dan Penerapannya. Yogyakarta: Pustaka Pelajar.
Riffaterre, Michael. 1978. Semiotics of Poetry. Bloomington: Indiana University Press.

Suthrell, Charlotte. 2004. Unzipping Gender: Sex, Cross-DressingandCulture. NewYork:Berg.

Sutrisno, Mudji, dkk. Culture Studies: Tantangan Bagi Teori-Teori Besar Kebudayaan. Depok: Koekoesan.

Ueda, Makoto. 1999. Light Verse from The Floating World. New York: Columbia University Press.

Yamamoto, Katsuo. (2010). TanoshikuHajimeruSenryu. Tokyo: Kinensh. 